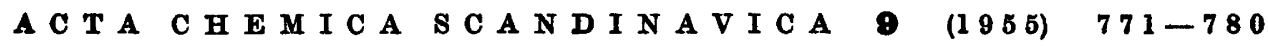

\title{
Studies on Aspartase
}

\section{Inactivation and Reactivation of Aspartase}

\author{
NILS ELLFOLK
}

Laboratory of the Foundation for Chemical Research, Biochemical Institute, Helsinki, Finland

\begin{abstract}
The inactivation of aspartase using prolonged dialysis, electrodialy sis and treatment with different forms of Amberlite IR-120 is described. Under carefully controlled conditions the partially inactivated enzyme was completely reactivated by incubation with different divalent metal ions. $\mathrm{Ca}++$ and $\mathrm{Mn}++$ proved to be the strongest activators even at low metal concentrations. Much higher concentrations of $\mathrm{Ba}^{++}, \mathrm{Sr}^{++}$and $\mathrm{Mg}^{++}$were needed to obtain the same activity. In. activators like $\mathrm{Co}++$ and $\mathrm{Pb}++$ seemed to produce a slight activation at low concentration. No activation or inactivation was obtained with $\mathrm{Ni}++, \mathrm{Fe}^{++}$, and $\mathrm{Zn}++$.
\end{abstract}

The first indications of the chemical nature of aspartase from propionic acid bacteria were obtained during the different attempts at purifying the enzyme. Its apparent instability was explained by the possible existence of a dissociable low molecular constituent ${ }^{1}$. Later, inhibition studies confirmed this assumption by suggesting one of the alkaline earth metal ions to be essential for the aspartase activity ${ }^{2}$.

In this paper attempts have been made to obtain a definite answer to the question of the nature of aspartase as a metallo protein. Therefore the enzyme was subjected to different treatments known to remove dissociable ions, i. e. prolonged dialysis, electrodialysis and treatment with ion exchange resins. Using these methods a strong inactivation of the enzyme was obtained. Attempts were made to reactivate the inactivated enzyme by addition of divalent metal ions. A good recovery of the enzyme activity was obtained with a preparation inactivated by a procedure that removed the metal rapidly from the enzyme. The enzyme used in this investigation was obtained from propionic acid bacteria.

\section{EXPERIMENTAL}

Enzyme preparation. Propionibacterium peterssonii (strain of this laboratory) was the starting material. A crude enzyme solution was prepared exactly as earlier described ${ }^{1}$. The enzyme solution was filtered by aid of Hyflo Super Cel.

Acta Chem. Scand. 9 (1955) No. 5 
Fig. 1. Continuous dialysis apparatus

a)

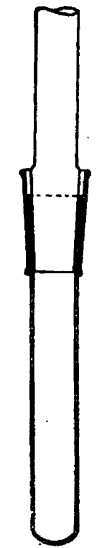

b)

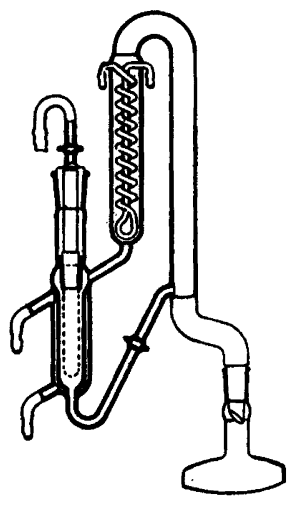

a) dialysis tube fitted between cone and socket

b) apparatus with the dialysis tube put in.

Activity measurements. The initial velocity of the reaction served as a measure of the enzymatic activity and was obtained exactly as earlier described ${ }^{1}$. The activity is expressed as a percentage of the initial velocity of the untreated enzyme preparation used as control.

The test solution was $0.02 M$ substrate (L-aspartic acid or fumaric acid and ammonia. The acids were neutralized with sodium hydroxide to $\mathrm{pH} 7.2$ ) in $0.007 M$ tris-(hydroxymethyl)-aminomethane buffer ${ }^{3}$ at $\mathrm{pH} 7.2$ in a final volume of $5 \mathrm{ml}$.

Ammonia was determined according to the method of Conway and O'Malley ${ }^{4}$ by distillation into alcoholic boric acid in Conway units and titrated with hydrochloric acid. The hydrogen ion concentration was determined with a glass electrode (Beckman). Protein nitrogen was determined by a micro-Kjeldahl method or, when results comparable with each other only were required, the relative protein concentrations were determined on the basis of the absorption at $280 \mathrm{~m} \mu$.

Analysis of metals. A qualitative determination of some metals was performed spectrophotometrically using a Beckman Model DU spetrophotometer with its original flame attachment. Hydrogen-oxygen was used as gas mixture.

Procedure for dialysis. The enzyme solution was subjected to prolonged dialysis against distilled water in vacuo using a continuous dialysis apparatus 5 .

The apparatus was operated in the following manner: The dialysis tube was attached to the cone of a ground glass joint and the corresponding socket so placed that the dialysis tube was firmly held in the cone and socket. The cone and socket were held by rubber bands.

The enzyme solution $(30 \mathrm{ml})$ was pipetted into the dialysis tube and the tube allowed to hang from the narrowing in the dialysis chamber in the apparatus (Fig. $1 \mathrm{~b}$ ). Distilled water was placed in the apparatus. The stopper was attached and the apparatus evacuated with a water pump. The distillation flask was heated and the condensed water ran into the dialysing chamber. The displaced water ran through the connecting tube to the distillation flask.

The enzyme activity and protein concentration were determined at regular intervals. The activity was calculated on the same protein content. After the dialysis experiment the distillation flask was analyzed on metals with a flame photometer.

Electrodialysis. The apparatus was of a design similar to that of Albers and Albers 6. Each compartment had a capacity of approximately $100 \mathrm{ml}$. The membranes between the compartments were of cellophane. The platinum electrodes were placed close to the membranes. The enzyme solution was placed in the middle compartment. The contents of the middle compartment were stirred to avoid precipitation on the membranes. 
Ion-exchange resins. Amberlite IR-120, analytical grade, was washed with water and treated with $5 \%$ hydrochloric acid until the solution remained strongly acid, after which it was washed with distilled water till the water remained nearly neutral (pH $\sim 6$ ). The sodium and calcium forms of the resin were prepared by treatment with $5 \%$ sodium and calcium chloride until all the hydrogen ions were displaced, $i$. $e$. the salt solution remained neutral (pH 6). The resins were dried at $40^{\circ} \mathrm{C}$.

The deionization experiments with the different forms of the resin were performed in the following way: $10 \mathrm{ml}$ of the enzyme solution were pipetted into a $100-\mathrm{ml}$ Erlenmayer flask and $1 \mathrm{~g}$ of resin was added. When a larger amount of enzyme solution was treated the same ratio between weight of resin and volume of enzyme solution was maintained. The flask was attached to a motor by means of a glass rod through its rubber stopper. The flask was allowed to spin in an oblique position to keep the resin moving continuously in the solution. The decrease in solvent volume was always taken into account in the calculations of activity.

Incubation experiments. A constant amount of enzyme was incubated with varying concentrations of metal ions in $0.007 M$ tris-(hydroxymethyl)-aminomethane buffer at $\mathrm{pH} 7.2 \mathrm{in}$ a final volume of $4 \mathrm{ml}$ at $20^{\circ} \mathrm{C}$ for $20 \mathrm{~h}$ with $0.03 \mathrm{ml}$ of toluene as antiseptic. The reaction was started by addition of aspartic acid to a final concentration of $0.02 M$ in $5 \mathrm{ml}$.

Fumarase activity. The fumarase activity of different enzyme preparations were determined by the spectrophotometric method of Racker ${ }^{7}$ using a Beckman model DU spectrophotometer. The test solution in a final volume of $5 \mathrm{ml}$ was $0.02 M$ fumarate in $0.007 M$ tris-(hydroxymethyl)-aminomethane buffer at $\mathrm{pH}$ 7.2. The reaction was started by addition of the enzyme to a concentration one third of that used in the activity determinations of aspartase. The change in the absorption at $300 \mathrm{~m} \mu$ and $20^{\circ} \mathrm{C}$ was recorded at suitable intervals. The control cell contained all components except fumarate.

\section{RESULTS}

A preliminary metal analysis was made on the enzyme preparation dialyzed against distilled water $(24 \mathrm{~h}$.) using a flame photometer (Beckman). Of the divalent metals only calcium could be detected by this technique. The following calcium bands were identified: $423 \mathrm{~m} \mu, 544 \mathrm{~m} \mu$ and $623 \mathrm{~m} \mu$. No magnesium bands could be detected in any preparation.

In order to elucidate the role of calcium in the activity of aspartase the activating ability of the $\mathrm{Ca}^{++}$ion was tested by incubating the enzyme at pH 7.2 and $20^{\circ} \mathrm{C}$ in a solution $0.01 M$ in respect to calcium chloride. $\mathrm{A}$ slight increase in the activity of the enzyme could be observed (Fig. 2). Accordingly it was decided to investigate the metal dependence of the enzyme activity in detail. The enzyme preparation was therefore subjected to a prolonged dialysis in a continuous dialysis apparatus in order to remove all dissociable ions. The effect of the dialysis was watched by determining the aspartase activity at regular intervals. The decrease of enzyme activity calculated on the same nitrogen content is shown in Fig. 3. The activity decreased continuously until it disappeared completely, after which the solution in the distillation flask was analyzed for metals. Of the divalent metals only calcium could be identified with the flame photometer. Reactivation of the inactivated enzyme was attempted by incubation at $\mathrm{pH} 7.2$ and $20^{\circ} \mathrm{C}$ in a solution $0.01 \mathrm{M}$ in respect to calcium chloride. Only a rather weak reactivation of the enzyme could be observed (Fig. 4). With another preparation no reactivation was noticed. This disagreement between the ability to reactivate the two preparations may have its explanation in some other factors, $e . g$. in the action of proteolytic enzymes decomposing the active protein during the prolonged experiment.

Acta Chem. Scand. 9 (1955) No. 5 


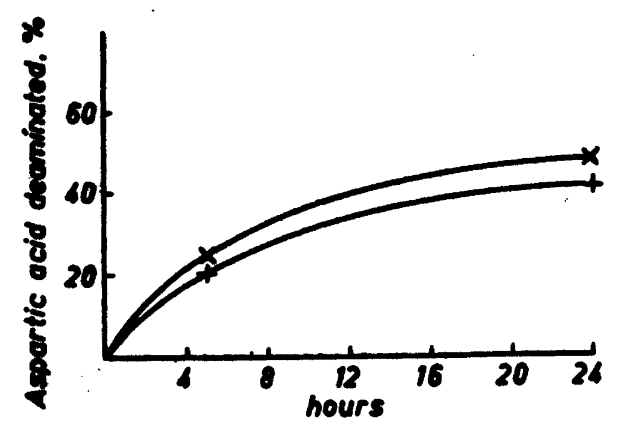

Fig. 2. Activating effect of calcium ion on the deamination of aspartic acid.

$\times$ proparation incubated in $0.01 \mathrm{M}$ calcium chloride

+ control without metal incubation.

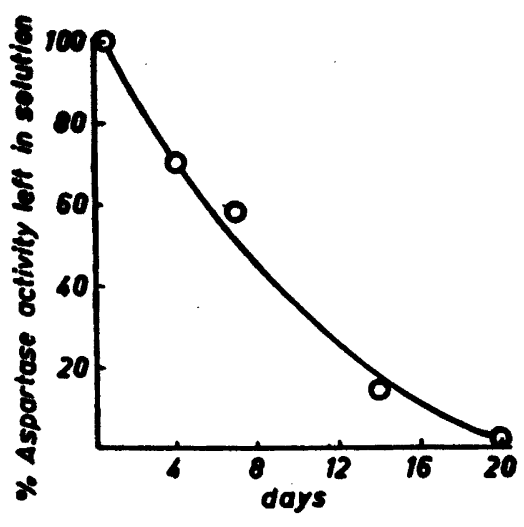

Fig. 3. Effect of prolonged dialysis on the activity of aspartase.

To avoid the disadvantages of prolonged dialysis when factors other than the removal of small ions from the enzyme may also contribute to the loss of enzyme activity, the enzyme was subjected to electrodialysis.

The experiments were carried out with a current of 6-8 $\mathrm{mA}$. In the first experiment the enzyme lost its activity completely within one hour. During this time the $\mathrm{pH}$ of the solution decreased to 3.2 and a strong precipitation of

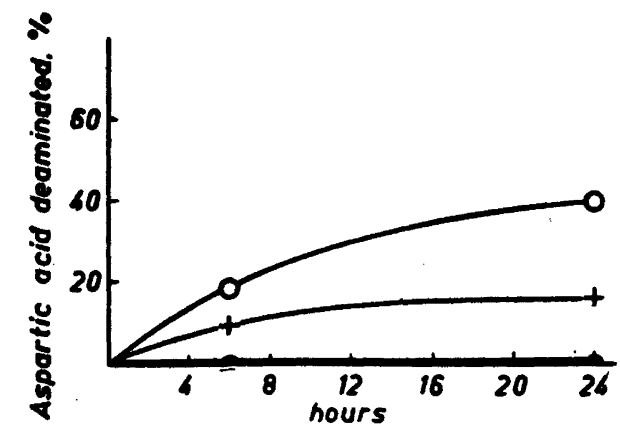

Fig. 4. Reactivating effect of calcium ion on aspartase inactivated by prolonged dialysis

+ dialyzed enzyme incubated in $0.01 \mathrm{M}$ calcium chloride

- dialyzed enzyme without metal incubation

O control with undialyzed enzyme.

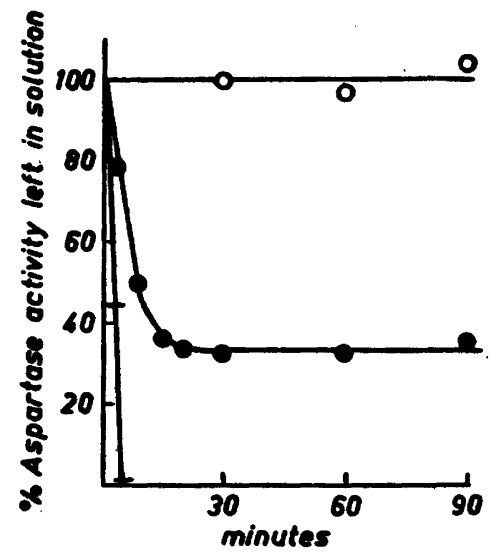

Fig. 5. Inactivating effect of resin treatment on the activity of aspartase

O treatment with Amberlite IR-120 (Ca)

treatment with Amberlite IR-120 (Na) + treatment with Amberlite IR-120 (H).

Acta Chem. Scand. 9 (1955) No. 5 


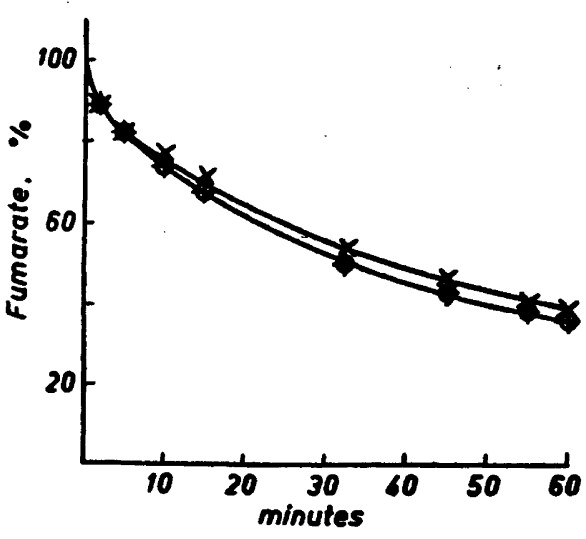

Fig. 6. Effect of resin treatment on the activity of fumarase

+ treatment with Amberlite IR-120 (Na)

$\times$ resin treated enzyme incubated in calcium chloride

- control without resin treatment.

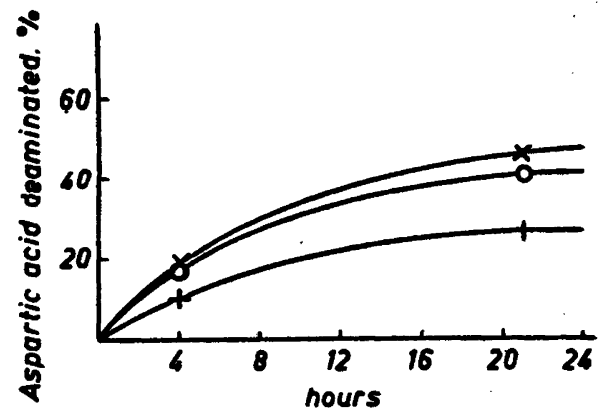

Fig. 7. Effect of resin treatment on the activity of aspartase

+ treatment with Amberlite IR-120 (Na)

$\times$ resin treated enzyme incubated in calcium chloride

- control without resin treatment.

protein occurred. Another experiment was carried out where the $\mathrm{pH}$ of the solution was kept constant by addition of alkali. After four hours the preparation had lost its activity completely. In spite of a thorough stirring of the solution during the experiment a strong precipitation of protein on the membranes could not be prevented. For this reason it is difficult to deoide if the inactivation of the preparation was due to the fact that the active metal was removed, or to a denaturation of the protein on the membranes. These experiments showed, however, that the preparation contains large anions not able to penetrate the membranes and small cations readily passing through. In both these experiments the solutions in the cathode compartments were analyzed for metals. The $\mathrm{Ca}$ bands mentioned above were again detected. When incubated with calcium chloride no reactivation was obtained with these enzyme preparations.

The ability of the cation exchange resin, Amberlite IR-120, to affect the activity of the enzyme was tested. The effect of the hydrogen sodium, and calcium forms of the resin on the enzyme is shown in Fig. 5. The comparison of the effect of the different forms of the resin shows that the Ca form had no inactivation power, whereas the sodium and hydrogen forms strongly inactivated the enzyme. With the sodium and calcium forms no change in the $\mathrm{pH}$ could be demonstrated. However, on using the hydrogen form of the resin, the $\mathrm{pH}$ of the solution fell rapidly to about 3 . (For the activity test the $\mathrm{pH}$ was adjusted to 7 by addition of a small amount of $0.1 \mathrm{~N}$ sodium hydroxide.)

Since aspartase catalyzes the reaction equilibrium

$$
\text { Aspartic acid } \rightleftharpoons \text { Fumaric acid }+ \text { Ammonia }
$$




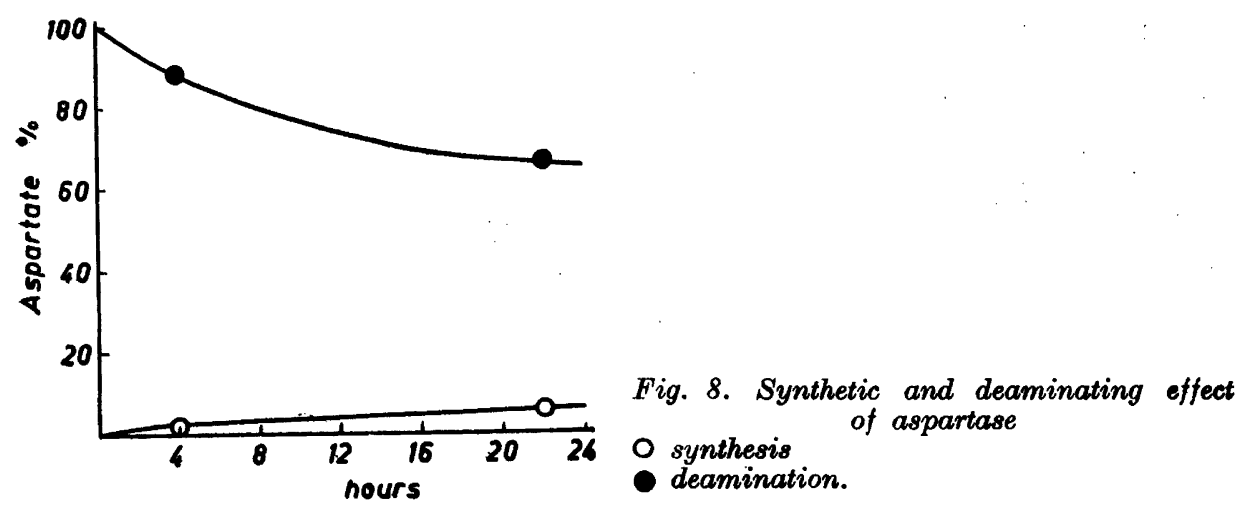

the observed metal dependence of the deamination activity may, of course be due to an activation of aspartase itself, but according to the reaction of equilibrium, any procedure able to decrease the effective concentration of fumaric acid should tend to drive the reaction to the right and so increase deamination at the expense of synthesis. In this case fumaric acid can be removed from the system either by the action of fumarase, converting it to malic acid or, in the presence of free divalent metal ions, by the formation of complexes between the metal and the acid, so decreasing the concentration of the effective acid.

The fumarase activity was determined after treating the enzyme preparation for $\mathbf{5 0}$ minutes with the sodium form of the resin as well as after incubation of such a preparation with calcium chloride for 20 h. at $20^{\circ} \mathrm{C}$ (Fig. 6). Activity determinations of aspartase were made simultaneously for the same preparations (Fig. 7). It can easily be seen that no change in fumarase activity was obtained, the activity of aspartase, on the contrary, being decreased by the resin treatment by about $50 \%$ and completely restored by incubation with calcium chloride, treatments without effect on the activity of fumarase, which is not a metal protein ${ }^{8}$.

From the experiments it can easily be seen that the fumarase activity of the preparations is so high that the fumarase equilibrium between fumaric and malic acid should always be established in experiments on aspartase, particularly as the activities in Fig. 6 are obtained at $20^{\circ} \mathrm{C}$ only and with enzyme concentrations one third of those used for the activity determinations of aspartase at $37^{\circ} \mathrm{C}$. (Fig. 7). Hence it is quite evident that the curves of deamination and synthesis of aspartic acid by aspartase fail to agree with each other mainly because of the action of fumarase in converting about $80 \%$ of the fumaric acid in the synthesis experiment to malic acid, before any synthesis of aspartic acid has taken place; moreover the malic acid should act as an inhibitor of aspartase. The difference in the deamination and synthetic activities of the same aspartase preparation can be seen in Fig. 8. The experiments are performed in the same molar concentration of substrates and are therefore comparable with each other.

To ascertain the extent to which the increase in the deamination activity may be due to a shift of the equilibrium toward deamination because of a 
Fig. 9. Effect of excess calcium ion on deamination of aspartic acid

+ deamination in $0.1 \mathrm{M}$ calcium chloride

O control without addition of calcium chloride.

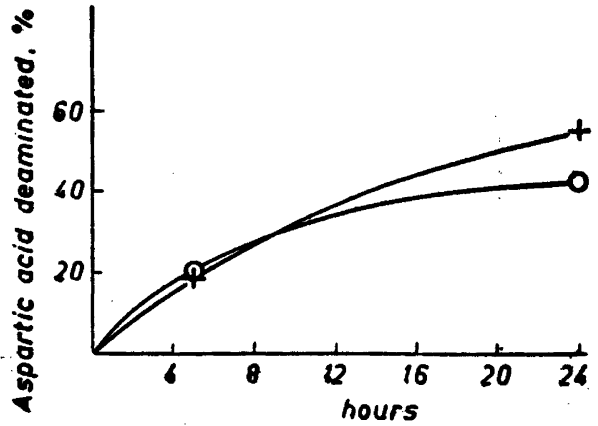

binding of effective fumaric acid in a complex with the activating metal ion in question, activity determinations were made in test solutions containing calcium ion in excess (Fig. 9). It is evident that a shift toward deamination can be obtained in this way, although it can be seen from the curves that no activation occurred. A similar shift toward deamination has earlier been shown by Jacobsohn and Pereira to occur with $\mathrm{Mg}^{++}$ion ${ }^{9}$. It appears that the activation cannot be explained in this way. Accordingly the main activation is due to the activation of aspartase itself.

Table 1. Reactivation of partially inactivated aspartase by incubating the enzyme with different metal ions at $20^{\circ} \mathrm{C}$ and $\mathrm{pH} 7.2$ for 20 hours.

\begin{tabular}{|c|c|c|c|}
\hline \multirow[b]{2}{*}{$\begin{array}{l}\text { Treatment of enzyme } \\
\text { before incubaton }\end{array}$} & \multicolumn{2}{|c|}{ Incubation } & \multirow[b]{2}{*}{$\begin{array}{c}\text { Activity as percentege } \\
\text { of control }\end{array}$} \\
\hline & Metal salt & $\begin{array}{c}\text { Final metal } \\
\text { concentration } \\
\text { Mole / } 1 .\end{array}$ & \\
\hline 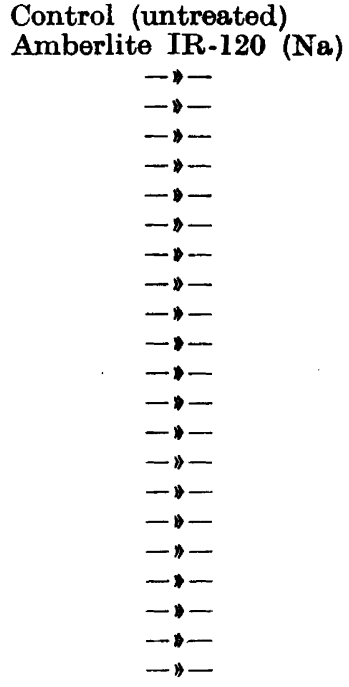 & $\begin{array}{l}- \\
\mathrm{CaCl}_{2} \\
\mathrm{CaCl}_{2} \\
\mathrm{CaCl}_{2} \\
\mathrm{CaCl}_{2} \\
\mathrm{CaCl}_{2} \\
\mathrm{MnCl}_{2} \\
\mathrm{MnCl}_{2} \\
\mathrm{MnCl}_{2} \\
\mathrm{MnCl}_{2} \\
\mathrm{MnCl}_{2} \\
\mathrm{BaCl}_{2} \\
\mathrm{BaCl}_{2} \\
\mathrm{SrCl}_{2} \\
\mathrm{SrCl}_{2} \\
\mathrm{MgCl}_{2} \\
\mathrm{MgCl}_{2} \\
\mathrm{CoCl}_{2} \\
\mathrm{NiCl}_{2} \\
\mathrm{FeCl}_{2} \\
\mathrm{ZnCl}_{2} \\
\mathrm{PbCl}_{2}\end{array}$ & $\begin{array}{l}\overline{-} \\
0.01 \\
0.001 \\
0.0001 \\
0.00001 \\
0.000001 \\
0.01 \\
0.001 \\
0.0001 \\
0.00001 \\
0.000001 \\
0.01 \\
0.001 \\
0.01 \\
0.001 \\
0.01 \\
0.001 \\
0.001 \\
0.001 \\
0.001 \\
0.001 \\
0.001\end{array}$ & $\begin{array}{r}100 \\
43 \\
103 \\
102 \\
90 \\
77 \\
44 \\
104 \\
101 \\
96 \\
88 \\
45 \\
80 \\
51 \\
100 \\
51 \\
100 \\
58 \\
54 \\
41 \\
19 \\
42 \\
51\end{array}$ \\
\hline
\end{tabular}

Acta Chem. Scand. 9 (1955) No. 5 


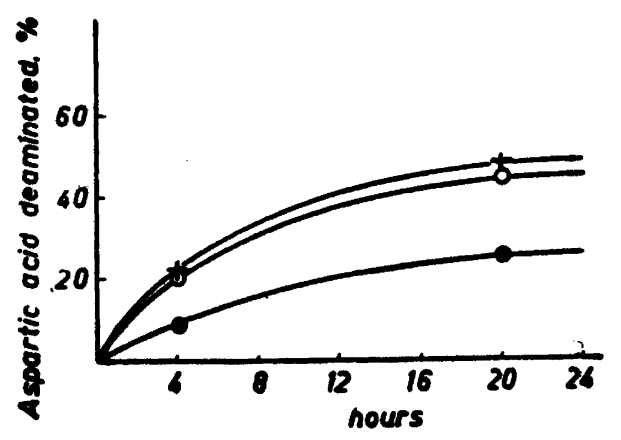

Fig. 10. Reactivation of resin treated aspartase (Amberlite IR-120 (H))

+ neutralized with calcium carbonate neutralized with sodium hydroxide control without resin treatmens.

To ascertain to what extent the activating power of calcium ions is shared by other divalent metal ions with known biological activity, the enzyme solution was deionized with the sodium form of IR-120 (50 min.) and incubsted with different metal ions. The final volume of the test solution was $5 \mathrm{ml}$. The reactivating power of the different metal salts can be seen in Table 1.

It can be seen from Table 1 that $\mathrm{Ca}^{++}$and $\mathrm{Mn}^{++}$showed the strongest reactivating power even at low concentrations. It is therefore evident that $\mathrm{Ca}^{++}$is the natural activator of the aspartase of propionic bacteria. Reactivation was also produced by such metal ions as $\mathrm{Mg}^{++}, \mathrm{Ba}^{++}$and $\mathrm{Sr}^{++}$, but at higher concentrations only. Metal ions like $\mathrm{Co}^{++}$and $\mathrm{Pb}^{++}$, earlier found to be inhibitors to the enzyme ${ }^{2}$, showed a slight reactivating power at low concentration. No activation or inactivation was produced at low concentrations by the metal inhibitors ${ }^{2} \mathrm{Ni}^{++}, \mathrm{Fe}^{++}$or $\mathrm{Zn}^{++}$.

In order to find out if the protein as such is inactive, attempts were made to obtain a complete inactivation but still keeping the reactivating ability unchanged. The enzyme was therefore rapidly inactivated with the hydrogen form of the resin and neutralized with solid calcium carbonate to about pH 6.5. The corresponding control was neutralized with sodium hydroxide to the same $\mathrm{pH}$. A complete reactivation was obtained using this technique if the $\mathrm{pH}$ of the solution was not allowed to fall below 4 (Fig. 10) during the resin treatment. If, however, the resin treatment was prolonged until the $\mathrm{pH}$ of the

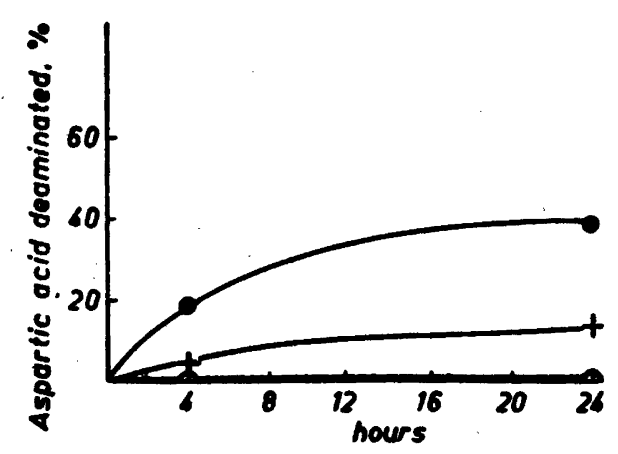

Fig. 11. Reactivation of resin treated aspartase (Amberlite IR-120 (H))

+ neutralized with calcium carbonate

o neutralized with sodium hydroxide

- control without resin treatment. 
solution was about 3 , no activity remained in the solution neutralized with sodium hydroxide, but when neutralized with solid calcium carbonate a slight reactivation was obtained (Fig. 11).

\section{DISCUSSION}

In a recent paper it was concluded from inhibition data that aspartase is a metal protein, one of the alkaline earth metals being essential for its activity $^{2}$. The present findings provide convincing evidence for this conclusion.

From the reactivation experiments it can be seen that aspartase has a low metal ion specificity, although the individual ions have different reactivating efficiency. In this respect aspartase shows similarities to peptidases ${ }^{10}$, carboxylases ${ }^{11}$ and phosphatases ${ }^{12}$. The interchangeability of the activating metal ions can be explained by considering the ways in which different metal ions form complexes. In biological systems the fixed $\mathrm{pH}$ (usually about 7) limits the types of complexes which various metal ions can form ${ }^{13}$. Thus it is known that metal ions such as the cupric ion will be bound in nitrogen complexes rather than in oxygen complexes; hence they will be bound to different groups in an enzyme than will cations such as $\mathrm{Mg}^{++}$and $\mathrm{Mn}^{++}$. Between the ions which behave like $\mathrm{Cu}^{++}, \mathrm{Ag}^{+}$, and $\mathrm{Pb}^{++}$, and those similar to $\mathrm{Mg}^{++}$, such as $\mathrm{Ca}^{++}$and $\mathrm{Mn}^{++}$, there will be a group which is intermediate in character, forming mixtures of oxygen and nitrogen compounds $i . e . \mathrm{Co}^{++}$, $\mathrm{Zu}^{++}$and $\mathrm{Cd}^{++}$. On adding an enzyme to a solution of a metal ion a complex of any of these three types will form depending on the nature of the metal. From earlier inhibition studies it was realized that the metal ion which activated aspartase formed strong oxygen complexes, a fact in good agreement with the findings in this paper that the oxygen complex-forming metal ions have the strongest activating power.

Recently Trudinger ${ }^{14}$ found that aspartase activity of toluene-treated cells of Proteus vulgaris sp. was stimulated by such metal ions as $\mathrm{Mg}^{++}, \mathrm{Mn}^{++}$and $\mathrm{Co}^{++}$only at substrate concentrations below $0.01 \mathrm{M}$. $\mathrm{Ca}^{++}$and $\mathrm{Ba}^{++}$had no activating effect, a finding contrary to that in this paper concerning the enzyme from propionic acid bacteria. Moreover, it is somewhat surprising that the activation is limited to low substrate concentrations only, so that, for instance, at a substrate concentration of about $0.02 M$ no activation could be observed. All the experiments in this paper were performed at $0.02 \mathrm{M}$ substrate concentration. It is true, however, that hardly any activation of the enzyme was obtained until it was partly inactivated by removing the metal, after which a complete reactivation of the original activity was obtained by incubation with divalent metals.

A difference was also observed by Trudinger between the activation of different bacteria, e.g. Aerobacter aerogenes exhibited a marked metal ion dependence while Esherichia coli, on the contrary, seemed to be less dependent on metal. ions.

From the experiments in this paper it can be concluded that at least $60 \%$ of the aspartase activity depends on activation by metals. Whether the protein component as such is completely inactive cannot be decided on the basis of these experiments. However, the possibility should not be entirely over- 
looked that the metal may be replaced by such groups as cationic $\mathrm{H}_{2} \mathrm{~N}^{+}=\mathrm{C}(\mathrm{NH})-\mathrm{NH}-$ or $\mathrm{H}_{3} \mathrm{~N}^{+}$-groups from arginine or lysine side-chains.

These positively charged loci with their ability to form hydrogen bonds could function in the same way as $\mathrm{Me}^{++}$. In such a case one might expect to find non-specific anion inhibitors for this enzyme, even though it is not metalactivated. However, the inhibition studies on aspartase from propionic acid bacteria are completely explained as an inhibition of the metal-activated enzyme, if it is assumed that only $60 \%$ of it is metal-activated.

I wish to express my sincere gratitude to Professor A. I. Virtanen for continued interest and valuable discussions in the work on aspartase.

\section{REFERENCES}

1. Ellfolk, N. Acta Chem. Scand. 7 (1953) 824.

2. Ellfolk, N. Acta Chem. Scand. 7 (1953) 1155.

3. Ellfolk, N. Acta Chem. Scand. 8 (1954) 443.

4. Gomori, G. Proc. Soc. Exptl. Biol. Med. 62 (1946) 33.

5. Manegold, E. Kolloid. Z. 78 (1937) 130.

6. Albers, H. and Albers, E. Hoppe-Seyler's Z. physiol. Chem. 232 (1935) 165.

7. Racker, E. Biochim. et Biophys. Acta 4 (1950) 211.

8. Massey, V. Biochem. J. (London) 53 (1953) 67.

9. Jacobsohn, K. P. and Pereira, F. B. Compt. rend. soc. biol. 120 (1935) 551.

10. Smith, E. Advances in Enzymol. 12 (1951) 191.

11. Ochoa, S. Physiol. Revs. 31 (1951) 56.

12. Roche, J. and Thai, N. V. Advances in Enzymol. 10 (1950) 83.

13. Williams, R. J. P. Biol. Revs. Cambridge Phil. Soc. 28 (1953) 381.

14. Trudinger, P. A. Australian J. Exptl. Biol. Med. Sci. 31 (1953) 319.

Received February: 28, 1955. 